\title{
Regulation of low-temperature tolerance in barley under field conditions in northwest Iran
}

\author{
S. Mahfoozi ${ }^{1}$, A. E. Limin'², F. Ahakpaz ${ }^{3}$, M. Roustaii ${ }^{3}$, H. Ketata ${ }^{4}$, and D. B. Fowler2,5 \\ ${ }^{1}$ Physiology-Agronomy Unit of Department of Cereals Research, Seed and Plant Improvement Institute, \\ P.O. Box 31585-4119, Karaj, Iran; ${ }^{2}$ Department of Plant Sciences, University of Saskatchewan, Saskatoon, \\ Saskatchewan, Canada S7N 5A8; ${ }^{3}$ Dryland Agricultural Research Institute, P.O. Box No. 119, Maragheh, Iran; \\ and ${ }^{4}$ International Center for Agricultural Research in the Dry Areas (ICARDA), Aleppo, Syria.
}

Received 13 December 2004, accepted 18 March 2005.

\begin{abstract}
Mahfoozi, S., Limin, A. E., Ahakpaz, F., Roustaii, M., Ketata, H. and Fowler, D. B. 2005. Regulation of low-temperature tolerance in barley under field conditions in northwest Iran. Can. J. Plant Sci. 85: 587-592. Low-temperature (LT) stress is a major factor limiting the over-winter survival of barley (Hordeum vulgare L.). The objective of this study was to determine the relationship between vegetative/reproductive transition and expression of LT tolerance in barley cultivars acclimated under field conditions. Three cultivars with different vernalization response and photoperiod sensitivity were planted in the field at the Maragheh Dryland Agricultural Research Station $\left(37^{\circ} 15^{\prime} \mathrm{N}, 46^{\circ} 15^{\prime} \mathrm{E} ; 1720 \mathrm{~m}\right)$ in Iran in the autumns of 2002 and 2003 . LT tolerance, as measured by $\mathrm{LT}_{50}$, and stage of phenological development, as estimated from final leaf number (FLN) and shoot apex developmental morphology, were determined during the autumn and winter seasons. The short-day insensitive spring-habit cultivar Rihane-03 had a limited ability to acclimate to LT and it reached its maximum level of LT tolerance very quickly. The winter-habit cultivar Dobrinya reached its maximum LT tolerance at the point of vernalization saturation. The very short-day (SD) sensitive spring-habit cultivar Dicktoo entered the double ridge (DR) stage at about the same time as the winter-habit Dobrinya. The delay in the phenological development of both Dobrinya and Dicktoo was accompanied by increased expression of LT tolerance confirming that the length of the vegetative phase determines a plant's ability to maintain a high level of cold-tolerance gene expression when temperatures are in the acclimation range. These observations suggest that more detailed studies should be initiated to establish the importance of interactions between photoperiod sensitivity and vernalization requirement with the objective of identifying genetic combinations and management systems that extend the vegetative stage and provide longer-term protection from LT stress in regions with long mild winters like those normally experienced in north-west Iran.
\end{abstract}

Key words: Vernalization, photoperiod, phenological development, freezing resistance, barley

Mahfoozi, S., Limin, A. E., Ahakpaz, F., Roustaii, M., Ketata, H. et Fowler, D. B. 2005. Régulation de la tolérance au froid chez l'orge de plein champ dans le nord-ouest de l'Iran. Can. J. Plant Sci. 85: 587-592. Le stress causé par le froid (SF) est l'un des principaux facteurs qui nuit à la survie générale de l'orge (Hordeum vulgare L.) à l'hiver. L'étude devait établir les liens entre le passage du stade végétatif au stade reproducteur et l'expression de la tolérance au froid chez les cultivars d'orge acclimatés et cultivés en pleine terre. À l'automne 2002 et 2003, les auteurs ont planté trois cultivars réagissant différemment à la vernalisation et à la photopériode dans des parcelles de la station de recherche sur l'aridoculture de Maragheh $\left(37^{\circ} 15^{\prime} \mathrm{N}, 46^{\circ} 15^{\prime} \mathrm{E}, 1720 \mathrm{~m}\right)$, en Iran. Ils ont mesuré la tolérance au froid (exprimée par le $\mathrm{SF}_{50}$ ) et estimé le stade phénologique (d'après le nombre final de feuilles et la morphologie de l'extrémité des pousses) à l'automne et en hiver. Le cultivar de printemps Rihane-03, insensible à la brièveté de la photopériode, s'acclimate mal au froid et atteint très vite son seuil de tolérance maximal. Le cultivar d'hiver Dobrinya atteint son seuil de tolérance maximal au froid au point de saturation de la vernalisation. Le cultivar de printemps Dicktoo, très sensible aux jours courts, entre dans le stade double ride à peu près au même moment que le cultivar d'hiver Dobrinya. Ce retard dans le développement phénologique de Dobrinya et de Dicktoo s'accompagne d'une plus forte expression de la tolérance au froid, signe que la durée de la phase végétative détermine bien l'aptitude de la plante à maintenir une forte expression du gène de tolérance au froid quand les températures se situent dans la fourchette de l'acclimatation. Ces observations laissent croire qu'on devrait entreprendre des études plus poussées afin d'établir l'importance des interactions entre la sensibilité à la photopériode et les exigences de la vernalisation, dans le but d'identifier les combinaisons génétiques et les systèmes de gestion qui prolongeront la phase végétative et assureront une meilleure tolérance au froid dans les régions caractérisées par de long hivers cléments comme ceux qu'on connaît habituellement dans le nord-ouest de l'Iran.

Mots clés: Vernalisation, photopériode, phénologie, résistance au gel, orge

Low-temperature stress is a major factor limiting barley survival in cold, high-altitude, mountainous areas of northwest Iran. Winter soil temperatures at crown depth normally fluc-

${ }^{5}$ To whom correspondence should be addressed (e-mail: Brian.Fowler@usask.ca). tuate around 0 to $-4^{\circ} \mathrm{C}$ in this region, with the result that the plants are exposed to variable periods of temperatures in the vernalization range. Because barley regulates its develop-

Abbreviations: FLN, final leaf number; DR, double ridge; LT, low-temperature; SD, short-day 
ment through adaptive mechanisms that are responsive to daylength and temperature, the unpredictable nature of the over-wintering period makes the selection of highly adapted genotypes for this region a difficult challenge.

Photoperiod and vernalization requirements are the two major mechanisms that control the transition from the vegetative to the reproductive phase in cereals. Vernalization is defined as the acceleration of the ability to flower by a chilling treatment (Chouard 1960). On low-temperature exposure, vernalization-requiring plants continue to restrict their FLN up to the point of vernalization saturation (Wang et al. 1995; Mahfoozi et al. 2001). Daylength is one of the most important environmental variables that influence the flowering of plants. Length of day affects apical morphogenesis, leaf production, tillering and other developmental processes in cereals (Kirby and Appleyard 1980). Long days accelerate floral initiation and heading by reducing the number of leaves in vernalized or spring barley plants (Pinthus and Nerson 1984). Under SD regimes, DR formation is delayed in sensitive genotypes (Lucas 1972; Mahfoozi et al. 2000) and the plants produce more leaves rather than a reproductive inflorescence (Holmes 1973; Mahfoozi et al. 2001) until a genetically determined maximum leaf number is attained (Pinthus 1985).

Low-temperature (LT) acclimation in cereals is a cumulative process characterized by a rapid initial response followed by a gradual reduction in rate of change until vernalization (Fowler et al. 1996) and/or photoperiod (Mahfoozi et al. 2000) requirements have been met. A close association between the vegetative/reproductive transition and the start of a decline in LT tolerance has demonstrated the regulatory influence that developmental genes have over LT-induced genes in cereals grown under controlled conditions (Fowler et al. 1999; 2001; Mahfoozi et al. 2001). If transition from the vegetative to the reproductive phase is the critical developmental switch that initiates the downregulation of LT tolerance genes, photoperiod and vernalization responses should interact to determine the level of LT tolerance gene expression (Mahfoozi et al. 2001).

The more complete our understanding of the complex genetic mechanisms that determine LT response and their interaction with the environment, the greater our ability to develop cultivars and management systems that minimize production risks and increase crop productivity. While a number of studies have investigated LT acclimation under field conditions (Fowler et al. 1999), detailed analyses of the interactions among photoperiod and vernalization requirements as they relate to winter crop adaptation have been restricted to controlled environments, the results of which must be validated under the highly variable conditions normally experienced in the field to have practical application. Consequently, the first objective of the present study was to clarify the relationship between vegetative/reproductive transition, which is regulated by photoperiod and vernalization responses, and control of LT tolerance in spring and winter-habit barley (Hordeum vulgare L.) plants vernalized and acclimated under field conditions in regions with long, mild winters, like northwest Iran. A second objective of this study was to provide a detailed analysis of the over-winter performance of selected cultivars to be used as references in winter barley breeding programs that target regions with long, mild winters where the length of the vegetative stage may be as important as the level of LT tolerance in determining winter survival.

\section{MATERIALS AND METHODS}

In this study, the term "winter habit" has been used to describe cultivars with a vernalization requirement, while "spring-habit" has been used to refer to cultivars that flower and set seed normally when planted in the spring, i.e., spring-habit cultivars do not have even a short vernalization requirement. Three cultivars that represented different reproductive strategies were selected for detailed evaluation in these studies. Dobrinya is a Russian winter-habit cultivar with a long vernalization requirement that has been widely distributed by ICARDA for use as a cold-hardy parent in regions with high stress winters. Rihane-03 is a short-dayinsensitive spring-habit cultivar that originated from ICARDA and has been widely grown in the regions of Iran that normally experience very mild winters. Dicktoo was included in these studies because it is a very short-day-sensitive cultivar that has been used extensively to study the effect of photoperiod requirements on the LT gene expression in controlled environments (Mahfoozi et al. 2000; Fowler et al. 2001) and in the molecular mapping of winter-hardiness genes (Hayes et al. 1997). Dicktoo does not have a vernalization requirement (Mahfoozi et al. 2000).

Phenological development and LT tolerance were determined for Dobrinya winter barley and Dicktoo and Rihane03 spring barley planted on 2002 Oct. 07 and 2003 Oct. 12 at the Maragheh Dryland Agricultural Research Institute (DARI) in Iran $\left(37^{\circ} 15^{\prime} \mathrm{N}, 46^{\circ} 15^{\prime} \mathrm{E} ; 1720 \mathrm{~m}\right)$. Expected daylengths (sunrise to sun set) for this location (Fig. 1) were determined using the online services (http://www.cavu.com/ sunsetexp.html) provided by Fly-By-Day Consulting, Inc. Soil temperatures at 5-cm depth and air temperatures (maximum and minimum) at shelter height were recorded from Sep. 01 to Mar. 31 (Fig. 2) using an on-location weather station. Plants for DR analysis and $\mathrm{LT}_{50}$ (temperature at which $50 \%$ of the plant are killed by LT stress) estimates were grown in the soil in the field, and plants for FLN determination were grown in pots (two plants pot ${ }^{-1}$ ) that were placed in the same field at the same time as the trials for DR analyses and $\mathrm{LT}_{50}$ determination were sown. Plants of each cultivar were sampled between Nov. 04 and Feb. 12 in 2002-2003 and between Nov. 07 and Feb. 14 in 2003-2004 to determine their stage of phenological development and LT tolerance.

Two methods were used to determine the stage of phenological development: (1) dissection of the plant crown to reveal the shoot apex development, and (2) the FLN procedure described by Mahfoozi et al. (2001). Shoot apices of plants taken from the field were dissected and photographed at each sampling date to determine the stage of development and identify when the DR stage had been reached. For determination of FLN, at each sampling date one pot from each replicate was moved into a glasshouse at $20^{\circ} \mathrm{C}$ and a $16-\mathrm{h}$ daylength starting Oct. 07 (planting date) and then on each 


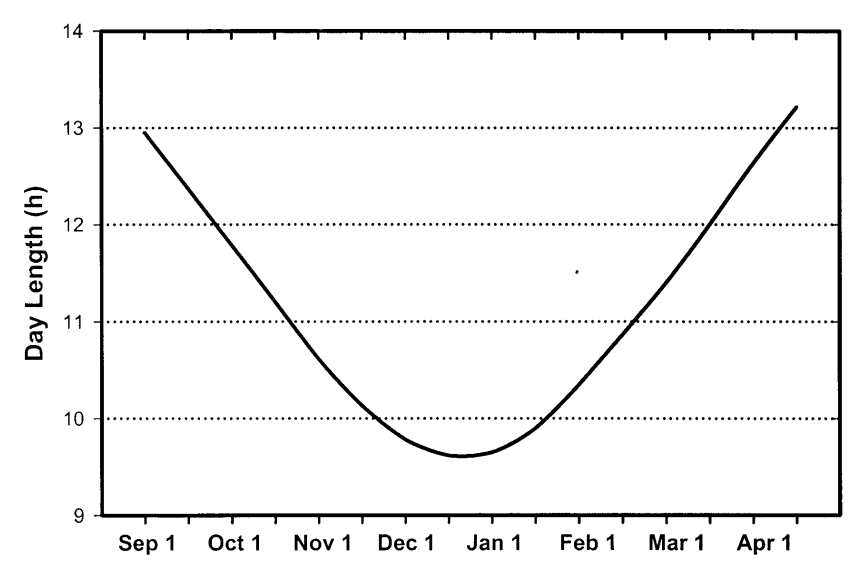

Fig. 1. Daylength (sunrise to sunset) at the Maragheh Dryland Agricultural Research Institute (DARI) in Iran $\left(37^{\circ} 15^{\prime} \mathrm{N}, 46^{\circ} 15^{\prime} \mathrm{E}\right.$; $1720 \mathrm{~m}$ ) determined using the online services provided by Fly-ByDay Consulting, Inc. (http://www.cavu.com/sunsetexp.html).
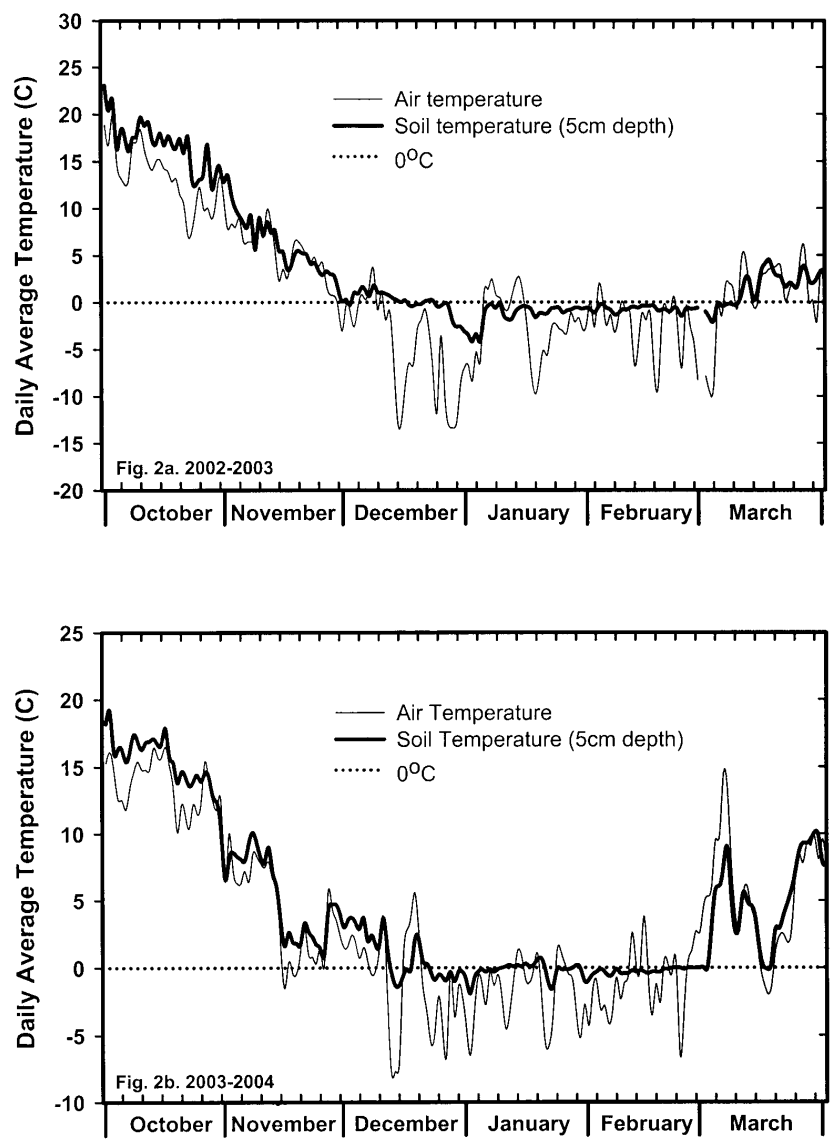

Fig. 2. Average daily air and soil temperature $\left({ }^{\circ} \mathrm{C}\right)$ at $5-\mathrm{cm}$ depth as recorded at the Maragheh Dryland Agricultural Research Station, Iran in 2002-2003 (Fig. 2a) and 2003-2004 (Fig. 2b).

of the subsequent sampling dates in the 2002-2003 trials. A similar procedure was followed starting Oct. 12 (planting date) in the 2003-2004 trials, except that the plants were moved into a glasshouse at $20^{\circ} \mathrm{C}$ and a 12 -h daylength, which was similar to the daylength in the field at the start of the experiment (Fig. 1). The leaves on the main stem of each plant were numbered until the flag leaf emerged. Transition from the vegetative to the reproductive stage was considered complete when the FLN for consecutive sampling dates became constant (Delecolle et al. 1989; Mahfoozi et al. 2001). The experimental design for the FLN trial was a 3 (genotype) $\times 8$ (sampling date) factorial in a two replicate randomized complete block design in both years of this study.

The experimental design for LT tolerance trial was a 3 (genotype) $\times 11$ (sampling date) randomized complete block factorial with two replicates in both 2002-2003 and 2003-2004. The procedure outlined by Limin and Fowler (1988) was used to determine the $\mathrm{LT}_{50}$ for plants collected from the field at each sampling date starting Oct. 27 in 2002 and Nov. 08 in 2003.

\section{RESULTS AND DISCUSSION}

Average daily $[($ maximum + minimum $) / 2]$ air and soil $(5 \mathrm{~cm}$ depth) temperatures recorded at Maragheh research station showed that there were favorable weather conditions for acclimation and vernalization in the field during the autumn and winter of 2002-2003 (Fig. 2a) and 2003-2004 (Fig. 2b). These temperatures were representative of the late autumn, winter, and early-spring weather normally expected in this region, and are typical of crop production areas with long, mild winters. Analysis of variance indicated that cultivar, sampling period, and the cultivar $\times$ sampling period interaction were highly significant for FLN and $\operatorname{LT}_{50}(P<0.01)$ in both years. A significant cultivar $\times$ sampling period interaction indicated that there were important differences among the cultivars in their rate of phenological development and LT acclimation under the field conditions experienced at this test site.

\section{Phenological Development}

When exposed to vernalizing temperatures, Dobrinya winter barley reduced its leaf number from 20.0 to 11.0 by Dec. 11 in 2002 (Fig. 3a) and from 23.5 to 12.0 by Dec. 27 in 2003 (Fig. 3b), indicating that it is a winter-habit genotype with a vernalization requirement (Wang et al. 1995; Mahfoozi et al. 2001). Spring-habit cultivars, such as Rihane-03 and Dicktoo, did not reduce their FLN when grown in the field at vernalization temperatures, indicating that they do not have a vernalization requirement. In fact, the very shortday-sensitive cultivar Dicktoo increased its FLN in response to the short photoperiod during acclimation in the field (Fig. $3 \mathrm{a}, \mathrm{b})$. These observations are consistent with earlier reports from controlled-environment studies at $20^{\circ} \mathrm{C}$ where Dicktoo had a FLN of eight leaves under a 20-h day and 26 leaves under an 8-h day (Mahfoozi et al. 2000, Fowler et al. 2001).

The activity of photoperiod-responsive genes is greater under warm than cool temperatures (Rahman and Wilson 1978; Yan and Wallace 1996), but the photoperiod-sensitive Dicktoo still produced 6.5 additional leaves $(\mathrm{FLN}=14.5)$ under 8-h compared to 20 -h days at $4{ }^{\circ} \mathrm{C}$ in a related study (Fowler et al. 2001). Similarily, Dicktoo increased its FLN from 9.0 to 11.0 in 2002-2003 (Fig. 3a) and from 14.5 to 

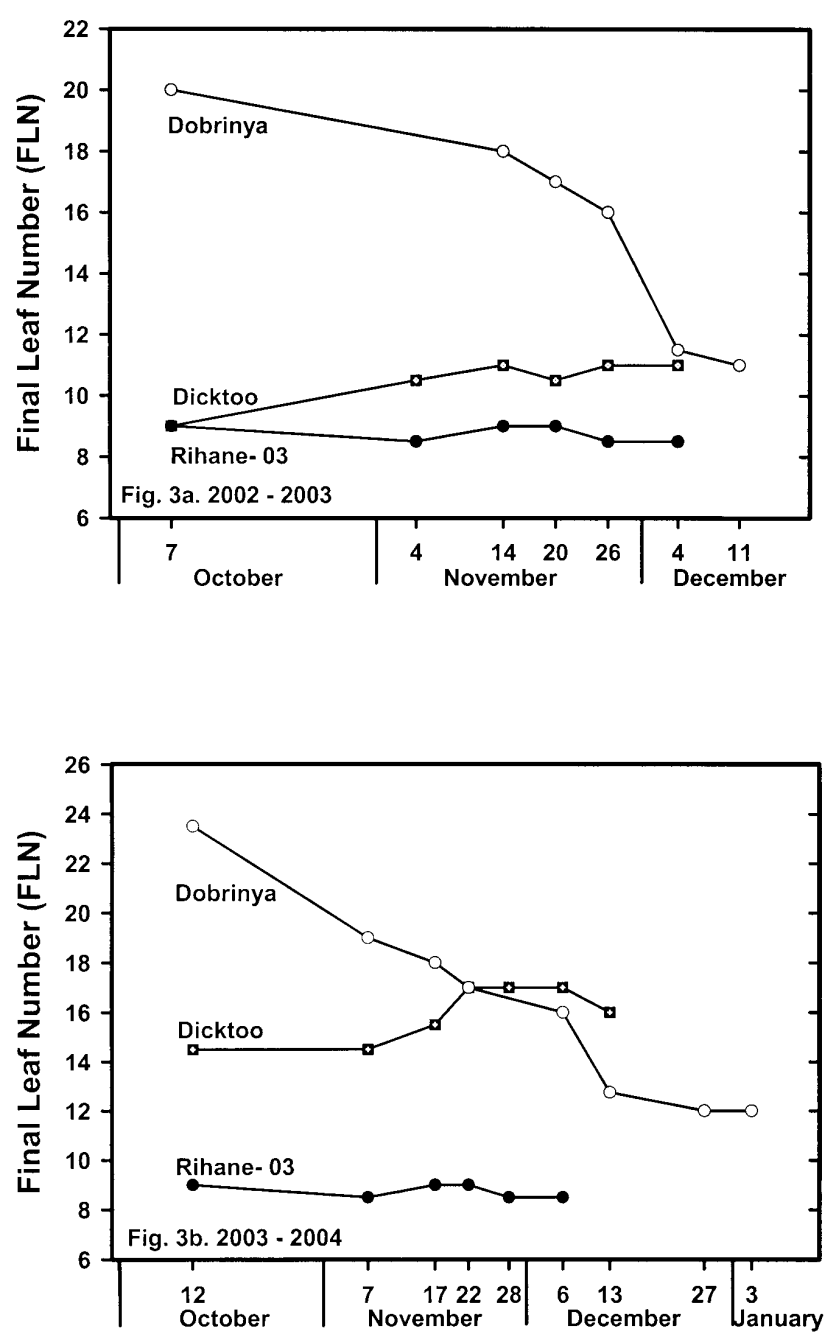

Fig. 3. Final leaf number (FLN) of Dobrinya winter barley, Rihane-03 spring barley and Dicktoo (very SD sensitive) spring barley grown in pots under field conditions and moved into a glasshouse at $20^{\circ} \mathrm{C}$ and 16-h and 12-h days, respectively, on the dates indicated in 2002-2003 (Fig. 3a) and 2003-2004 (Fig. 3b). The 2002 Oct. 07 and 2003 Oct. 12 pots were moved directly into a glasshouse at $20^{\circ} \mathrm{C}$ and $16-\mathrm{h}$ and 12 -h days, respectively, at the time of planting. $\mathrm{SE}=0.4$ in both years.

17.0 in 2003-2004 (Fig. 3b) when grown under the decreasing autumn daylength (Fig. 1) in the field at Maragheh, Iran. As expected, the FLN of Dicktoo increased by 5.5 leaves (9.0 to 14.5) when potted plants were placed directly in the glasshouse at 16-h (2002-2003) compared with 12-h days at the time of planting (Fig. 3). An increase in the FLN for the winter-habit Dobrinya when grown under 12-h compared with 16-h days suggests that, in addition to a vernalization requirement, its vegetative/reproductive transition is also delayed when exposed to short days. The spring-habit Rihane-03 did not respond to vernalization or short daylength.

Initiation of floral primordia is determined by genotype and environment interactions, which in turn determine the
FLN produced by the main stem (Hay and Ellis 1998; McMaster 1997). Fulfilment of the LT requirement (vernalization saturation), which is also an indication of the point of transition from the vegetative to the reproductive stage (Mahfoozi et al., 2001), is considered complete once the LT treatment no longer reduces FLN (Wang et al. 1995; Mahfoozi et al. 2001). FLN measurements indicated that Dobrinya winter barley achieved vernalization saturation by Dec. 11 in 2002-2003 (Fig. 3a) and by Dec. 27 in 2003-2004 (Fig. 3b) under the field conditions experienced at Maragheh, Iran.

Double ridge formation is another indication that transition to the reproductive stage has taken place (McMaster 1997). The DR stage occurred between Oct. 31 and Nov. 03 in the SD-insensitive spring barley cultivar Rihane-03 (Fig. 4), which was shortly after planting. In contrast, DRs were not visible until much later (Dec. 06 in 2002 and Dec. 20 in 2003) in Dicktoo, the SD-sensitive spring barley, indicating that SD sensitivity delayed the vegetative/reproductive transition under field conditions. The fact that Dicktoo reached its vegetative/reproductive transition near mid-December (Fig. 4), when the daylength had decreased to less than $10 \mathrm{~h}$ (Fig.1), also agrees with earlier observations (Mahfoozi et al. 2000; Fowler et al. 2001) that short daylength will not maintain sensitive plants in the vegetative stage indefinitely. The DR stage was also visible in Dobrinya winter barley by Dec. 06 in 2002 and Dec. 20 in 2003 showing that strong photoperiod sensitivity can be as important as a vernalization requirement in determining the length of the vegetative stage in autumn-sown barley in this region of Iran.

\section{Low-temperature Tolerance and Crop Adaptation}

Dobrynia winter barley started to acclimate very quickly in early November (Fig. 5a, b), once soil temperatures dropped into the acclimation range (Fig. 2a, b). The rate of change in LT tolerance then gradually slowed and reached a maximum by Nov. 28 in 2002 (Fig. 5a) and Dec. 20 in 2003 (Fig. 5b), which coincided with vernalization saturation as determined from FLN measurements. DR was also visible by 2002 Dec. 06 and 2003 Dec. 20 in this cultivar (Fig. 4b). These observations support the conclusion that the signal ending the vegetative phase corresponds closely to the start of LT tolerance loss in genotypes like Dobrynia, which have a vernalization requirement (Fowler et al. 1996; Mahfoozi et al. 2001).

Rihane-03 spring barley, which had limited ability to cold acclimate (Fig. 5), reached the reproductive stage (Fig. 3a, b) and formed DRs (Fig. 4) between Oct. 31 and Nov. 03. In contrast, the SD-sensitive Dicktoo spring barley had a longer vegetative phase (Fig. 3a, b), which delayed its transition to the reproductive stage (Fig. 4). A higher level and longer duration of expression of LT tolerance was associated with this extended vegetative stage with the result that Dicktoo had a pattern of acclimation and achieved a LT tolerance level similar to Dobrinya winter barley (Fig. 5a, b).

The results of this field study show that photoperiod response and vernalization requirements interact with temperature to influence the rate of phenological development and the expression of LT tolerance genes. They provide data 


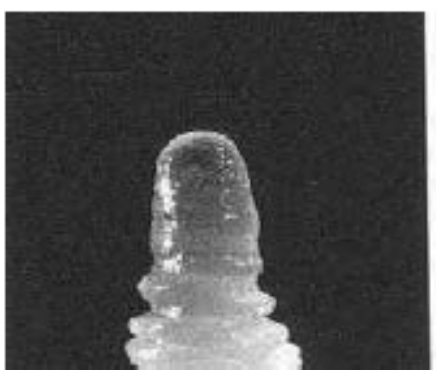

Fig. 4a

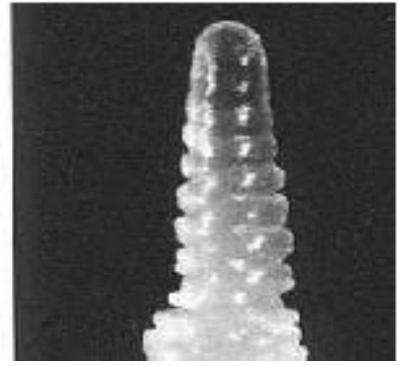

Fig. 4b

Fig. 4. Comparative apical development to double ridge (DR) formation of Dobrinya winter barley plus Rihane-03 (SD insensitive) and Dicktoo (very SD sensitive) spring barley cultivars. Fig. 4a shows the average stage of apical development of Dicktoo and Dobrinya on Nov. 28. Fig. 4b shows DR formation between Oct. 31 and Nov. 03 in Rihane-03 and by 2002 Dec. 06 and 2003 Dec. 20 in Dobrinya and Dicktoo.
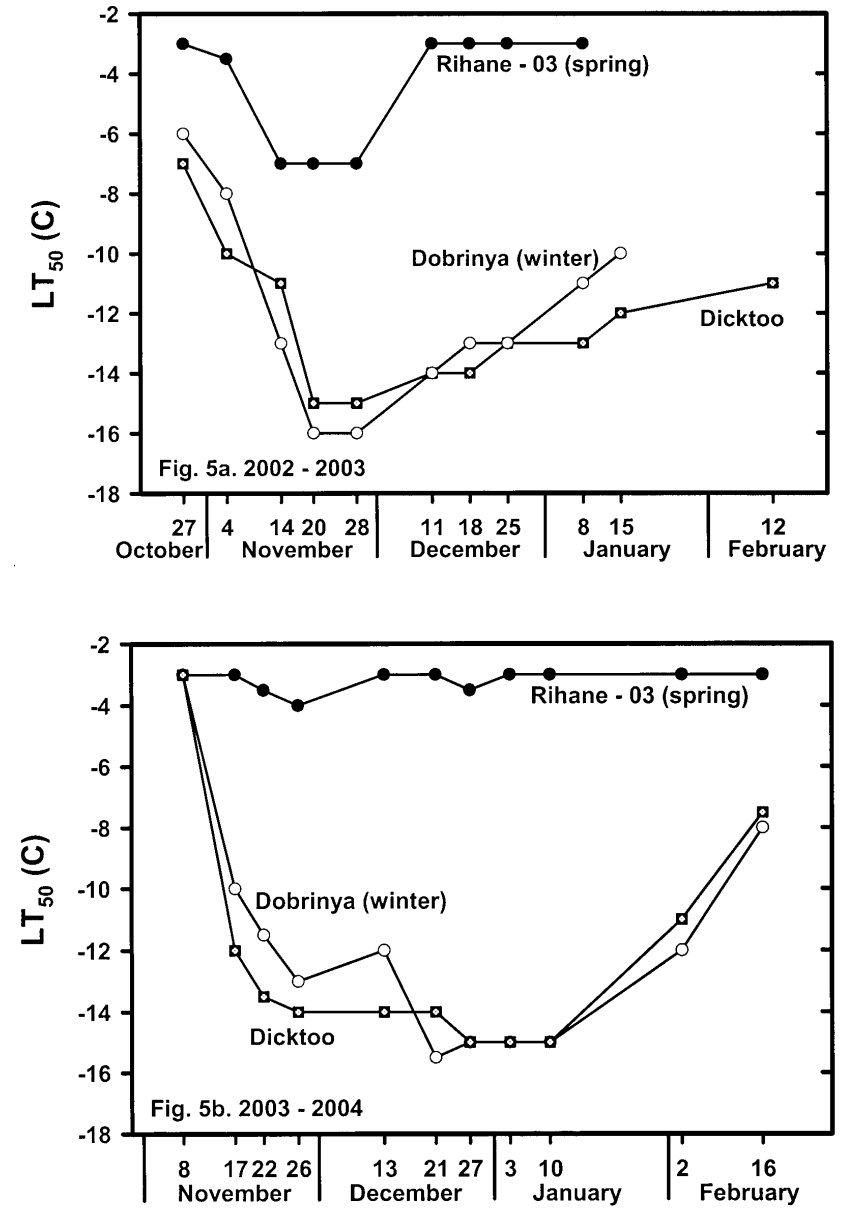

Fig. 5. Low-temperature tolerance of Dobrinya winter barley and Rihane-03 (SD insensitive) and Dicktoo (very SD day sensitive) spring barley grown under field conditions of Maragheh Dryland Agricultural Research Station, Iran in 2002-2003 (Fig. 5a) and 2003-2004 (Fig. 5b). 2002-2003 SE = 0.4; 2003-2004 SE = 0.6.

from natural environments that verify reports from controlled-environment studies that vernalization requirement (Fowler et al. 1996; Mahfoozi et al. 2001) and SD photoperiod sensitivity (Mahfoozi et al. 2000, 2001; Fowler et al. 2001) are separate pathways that plants have evolved to delay the onset of the reproductive phase, thereby allowing LT tolerance genes to be expressed for a longer period of time at temperatures in the LT acclimation range and optimally timing flowering. They also support the observations from controlled-environment studies indicating that any factor that delays transition from the vegetative to the reproductive phase allows increased duration of expression of LT tolerance genes (Fowler and Limin 2004; Prasil et al. 2004) and that the time of transition from the vegetative to the reproductive stage corresponds to the beginning of a loss of LT tolerance in cereals.

Vernalization and photoperiod requirements allowed barley to attain a moderate level of LT tolerance in the autumn and early winter under field conditions at Maragheh, Iran (Fig. 5a, 5). However, the level of LT tolerance gradually diminished starting after the vegetative/reproductive transition had been reached, with the result that the plants became more vulnerable to sudden temperature drops in the late winter and early spring. This suggests that, for species adapted to regions with long, mild winters, a high level of freezing tolerance may be less important than a photoperiod, dormancy, or vernalization requirement that prevents the plants from entering the extremely cold-sensitive reproductive growth stage until the risk of LT damage has passed. These observations indicate that further studies are required to determine the interactions among photoperiod sensitivity and vernalization requirement with the objective of identifying genetic combinations that extend the vegetative stage thereby providing the opportunity for longer-term protection from LT stress in regions with long, mild winters like those normally experienced in the Maragheh region of north-west Iran.

\section{ACKNOWLEDGMENTS}

Financial support provided for this study by The Agricultural Research and Education Organization (AREO) of the Agricultural Ministry of Iran is gratefully acknowledged.

Chouard, P. 1960. Vernalization and its relations to dormancy. Ann. Rev. Plant Phys. 11: 191-238.

Delecolle, R., Hay, R. K. M., Guerif, M., Pluchard, P. and Varlet-Grancher, C. 1989. A method of describing the progress of apical development in wheat, based on the time-course of organogenesis. Field Crops Res. 21: 147-160. 
Fowler, D. B., Breton, G., Limin, A. E., Mahfoozi, S. and Sarhan, F. 2001. Photoperiod and temperature interactions regulate low-temperature-induced gene expression in barley. Plant Phys. 127: 1676-1681.

Fowler, D. B. and Limin, A. E. 2004. Interactions among factors regulating phenological development and acclimation rate determine low-temperature tolerance in wheat. Ann. Bot. 94: 717-724.

Fowler, D. B., Limin, A. E. and Ritchie, J. T. 1999. Low-temperature tolerance in cereals: model and genetic interpretation. Crop Sci. 39: 626-633.

Fowler, D. B., Limin, A. E., Wang, S. Y. and Ward, R. W. 1996. Relationship between low-temperature tolerance and vernalization response in wheat and rye. Can. J. Plant Sci. 76: 37-42.

Hay, R. K. M. and Ellis, R. P. 1998. The control of flowering in wheat and barley: what recent advances in molecular genetics can reveal. Ann. Bot. 82: 541-554.

Hayes, P. M., Chen, F. Q., Corey, A., Pan, A., Chen, T. H. H., Baird, E., Powell, W., Thomas, W., Waugh, R., Bedo, Z., Karsai, I., Blake, T. and Oberthur, L. 1997. The Dicktoo $\times$ Morex population: a model for dissecting components of winter hardiness in barley. In P. H. Li and T. H. Chen, eds. Plant cold hardiness. Plenum Press, New York, NY.

Holmes, D. P. 1973. Inflorescence development of semidwarf and standard height wheat cultivars in different photoperiod and nitrogen treatments. Can. J. Bot. 51: 941-956.

Kirby, K. J. M. and Appleyard, M. 1980. Effects of photoperiod on the relation between development and yield per plant of a range of spring barley varieties. Z. Pflanzenzuchtg. 85: 226-239.

Limin, A. E. and Fowler, D. B. 1988. Cold hardiness expression in interspecific hybrids and amphiploids of the Triticeae. Genome 30: $361-365$.
Lucas, D. 1972. The effect of day length in primordia production of the wheat apex. Aust. J. Biol. Sci. 25: 649-656.

Mahfoozi. S., Limin, A. E. and Fowler, D. B. 2001. Developmental regulation of low-temperature tolerance in winter wheat. Ann. Bot. 87: 751-757.

Mahfoozi. S., Limin, A. E., Hayes, P. M., Hucl, P. and Fowler, D. B. 2000. Influence of photoperiod response in the expression of cold hardiness in wheat and barley. Can. J. Plant Sci. 80: 721-724. McMaster, G. S. 1997. Phenology, development, and growth of the wheat (Triticum aestivum L.) shoot apex: A review. Adv. Agron. 59: 63-118.

Pinthus, M. J. 1985. Triticum. Pages 418-443 in A. H. Halevy, ed. Handbook of flowering. Vol. IV. CRC Press, Boca Raton, FL.

Pinthus, M. J. and Nerson, H. 1984. Effect of photoperiod at different growth stages on the initiation of spikelet primordia in wheat. Aust. J. Plant Phys. 11: 17-22.

Prasil, I. T., Prasilova, P. and Pankova, K. 2004. Relationships among vernalization, shoot apex development and frost tolerance in wheat. Ann. Bot. 94: 413-418.

Rahman, M. S. and Wilson, J. H. 1978. Determination of spikelet number in wheat. III. Effect of varying temperature on ear development. Aust. J. Agric. Res. 29: 495-467.

Wang, S. Y., Ward, R. W., Ritchie, J. T., Fischer, R. A. and Schulthess, U. 1995. Vernalization in wheat. I. A model based on the interchangeability of plant age and vernalization duration. Field Crops Res. 41: 91-100.

Yan , W. and Wallace, D. H. 1996. A model of photoperiod by temperature interaction effects on plant development. Crit. Rev. Plant Sci. 15: 63-96. 